\title{
Consolidation of Regional Groupings and Economic Growth: Empirical Investigation by Panel Data
}

\author{
Bassem Kahouli • Noureddine Kadhraoui
}

Published online: 13 November 2012

(C) EMUNI 2012

\begin{abstract}
Regional groupings have changed the trade flows in favor of intra zone and at the expense of trade between regions. These groupings are not without effects on growth and well being. In this sense, economic integration is an aspect of a wider strategy to promote growth and development. This article focuses on the study of the influence of regional integration on economic growth in several groups over the period 1970-2009. It introduces several variables related to economic integration (opening rate, FDI, R\&D and dummies variables) to test their effects on growth in these countries. This study examines a panel of 40 countries and 10 in successive 5-year periods. The results found show the existence of a strong relationship between the factors of economic integration and growth in these countries.
\end{abstract}

Keywords Regional Economic Integration · Economic Growth · Panel Data

JEL Classification $\mathrm{F} 13 \cdot \mathrm{F} 15 \cdot \mathrm{F} 43 \cdot \mathrm{C} 23$

\section{Introduction}

In recent decades, there has been an unprecedented number of regional agreements which constitutes one of the crucial characteristics of international economic relations. Many countries have begun to explore and participate in RIA. At this point, Cheru (2002) reported that since the end of the Cold War and with the emergence of powerful trading blocs, there was a renewed interest in several

B. Kahouli $(\bowtie) \cdot$ N. Kadhraoui

Member of the Research Unit Tourism and Development,

FDSEP, Sousse, Tunisia

e-mail: kahoulibassem@yahoo.fr

N. Kadhraoui

e-mail: kadnoured@gmail.com 
countries on the need to create mechanisms economic integration to promote economic growth. At this level, several preferential trade agreements have been established in most parts of the world: Europe (EU and its successive enlargements), North America (NAFTA), Latin America (MERCOSUR), Asia Pacific (APEC, ASEAN, CER), Caribbean Community (CARICOM), Africa (UEMOA, SADC, UMA,...), and others. Although most of the agreements of integration are regional in the geographical sense, some of them relate to countries far away geographically, see located on different continents (e.g, EU-ACP). Among the experiences of integration, the EU is the model of economic integration the most successful. This work focuses on economic aspects of regional integration, and their importance for the various parties. Thus, to understand the links and intersections this can exist between the two variables of this research and its impact on member countries and third countries. Similarly, an attempt to test empirically the impact of regional economic integration on growth and development. Otherwise, we try to answer the following questions: regional groupings and economic relations can play a fundamental role in economic growth? In what measure does the intensification of the agreements of association and the promotion of a free trade area favor the reduction of the regional disparities and the economic development?

This work is organized as follows. The second section is a review of the theoretical and empirical literature on this subject, and gives attention to traditional and modern theories of economic integration. Otherwise, it shows the original item on the integration of theories to show how they have evolved over time. The third section presents the different stages of integration and determines the specificity of each phase of integration. The presentation of our estimation model and the results of econometric tests are available in the fourth section, to draw conclusions and make policy recommendations (Sect. 5).

\section{Economic Integration and Growth: A Review of the Theoretical and Empirical Literature}

The Theoretical Work

Many economists were interested in the link between economic integration and economic growth in a country. From liberal point, integration follows from the classical theory of international trade. Economic integration reduces to trade liberalization and implementation of an international business unit to which the products are exchanged against the abundant scarce goods under a regime of free trade, Kabunda (2005). The classical theory of international trade is rooted in the concept of comparative advantage. ${ }^{1}$ The extension of this theory by that of HOS confirmed these gains and has added others related to the remuneration of production factors. The HOS model is based on the international exchange of differences in relative endowments of

\footnotetext{
1 This concept was mentioned by Ricardo and can be interpreted as a particular phase of global economic integration in which the starting point is an international system composed of a group of closed national markets, and the end point is a perfectly integrated world market where capital and labor circulate freely.
} 
factors. This model is often considered as adopted in the study of trade integration between countries. In the same order of idea, the effects of the integration are estimated using the concepts of Viner (1950) creation and diversion of trade. Carbaugh (2004) considers that the trade creation occurs when domestic production of a member of the customs union is replaced by imports from another member whose production costs are lower. So there is a better allocation of resources and the union is advantageous. The trade diversion occurs when imports of a low-cost supplier outside the union are replaced by higher cost of purchases from a supplier within the union, then there is a bad allowance of the resources and the union is disadvantageous. These deviations of trade correspond to the effects of a change of the system price of exchange, resulting in the formation of a customs union, a more efficient use of resources and the welfare of member countries. The analysis of Viner (1950) was extended by Meade (1955), Lipsey $(1957,1960)$ and Gehrels (1957) to the effects of consumption ${ }^{2}$ resulting from the formation of a customs union or free trade zone (FTA). We can also announce work concerning the theory of optimum currency areas Mundell (1957) which deals with monetary integration. It is a specific approach which focuses on relations between countries, regions and currencies which try to evaluate the appropriateness of the monetary union between countries. The monetary union is expected to produce economic benefits, such as the elimination of transaction costs. However, it implies for the acceding countries to give each their own monetary policy. In the same order, the theory of fiscal federalism, Oates (1972) and King (1984) which deals with issues related to taxation and the coordination of fiscal policies in a set of associated states. However, this liberal approach to integration is not consistent with historical experience, especially for developing countries. ${ }^{3}$ In addition, these traditional theories cannot explain the interaction between similar countries, intra-industry and neglects the role of multinational firms.

The importance of the role played by multinational firms is a sign of imperfect competition. In this context, Baldwin and Venables (1995) express that the impacts of economic integration will be much higher if we consider firms in imperfect competition rather than perfect competition. In fact, the relative factor endowments and comparative advantages are not fixed but in a state of permanent change. The literature of the new economic geography (NEG) explores a certain number of mechanisms which make endogenous the concept of comparative advantage Krugman (1981, 1991, 1995), Krugman and Venables (1995), Feenestra (1990) and Grossman and Helpman (1991). The synthesis geography growth appears to be an adequate framework for analyzing integration and the growth particularly in the case of the countries of different level in development. We can say therefore that the analysis and understanding of the mechanisms of integration and growth come from the merger of two theoretical fields such as the new economic geography initiated ${ }^{4}$

\footnotetext{
2 The effect of consumption corresponds to the profit in terms of consumer surplus generated by the lower prices that could increase demand for imports.

35 Two general reasons are behind this. The first is that liberal theory is based on assumptions that are violated in most markets; the second is that trade relations are not conducted within a framework of perfect competition.

4 The new economic geography (the new trade theory) can be defined as an approach to world trade with a focus on two aspects missing in the traditional theory: increasing returns and imperfect competition.
} 
by Krugman (1991) and endogenous growth, ${ }^{5}$ initiated by Romer (1990) and Lucas (1988). The mechanisms described and the economic and geographic variables used appear appropriate to take into account the economic and regional integration, the search for growth and economic and social cohesion. The new economic geography and endogenous growth share common points. Both theories are based on the principles of increasing returns and imperfect competition. These two principles explain, firstly, the importance of intra-industry trade in international trade and also the innovation and growth, Abdeljabbar and Hanchane (2004).

In summary, ${ }^{6}$ the theoretical studies failed to decide whether or not economic integration contributes to economic growth. We will review the empirical literature to try to see there more clearly.

\section{Empirical Work}

The purpose of this section is to summarize some empirical studies that have investigated the effects of economic integration on growth. At this level, it is to distinguish two periods. Over 70 years, empirical works explaining the relationship between economic integration and growth generally use cross-sectional regressions on a set of countries. Abdeljabbar and Hanchane (2004) informed that these studies focus on the relationship between exports and economic growth or the relationship between growth and indicators of openness and trade policies. The second period is characterized by the fusion of the endogenous growth theory and new trade theory. The work was focused on the ways of influence of openness on growth: the formation of physical capital (imported goods), human capital and knowledge (diffusion). These two periods have allowed researchers to focus on ways the richest in terms of analysis.

Several empirical studies have attempted to verify the theoretical results. In this context, the study of Romer (1990) on a sample of 112 countries over the period 1960-1985 shows that the rate of growth of exports accelerates technological progress and creates a direct effect on growth of the income per capita. Romer concluded that the potential opportunities of investment represent in the long run for developing countries an essential catalyst for the growth process. In addition, the work of Coe and Helpman (1995) of the 22 OECD countries over the period (1974-1990) show that the intensity of externalities in international R\&D increases with the opening of the country. The TFP of a country depends not only on its own stock of R\&D but also that of these trading partners. Similarly, small countries profit from an elasticity of their PGF compared to the global R\&D is greater. The small countries are likely to gain more than large countries with the opening. Similarly, Haveman (1998) attempted to distinguish the effects on the growth of various forms of international integration. ${ }^{7}$ On a panel of 74 countries covering the period

\footnotetext{
5 Endogenous growth theories offer a framework for the development of open economy models, where it can demonstrate the existence of long-term effects via technical progress and transfer of technology, Abdeljabbar and Hanchane (2004).

6 See Appendix (Table 7): Theoretical Contribution of Regional Integration.

7 The reduction of trade barriers international, the role of the foreign direct investments flows and finally the membership in a commercial block.
} 
1970-1989, the authors introduced simultaneously three types of variables measuring international integration. According to their results, the opening to the outside, as measured by trade intensity has a positive and significant influence on growth. The FDI also has a significant positive effect on growth. In the same direction, we can quote the work of Guillaumont (2002) which examines the role of trade between the member countries of the EU and France in economic growth of this last one. The data used are GDP, exports and imports for two periods: 1854-1913 and 1957-1999. The Co-integration tests have shown that there is a long-term relationship between the French exports to the EU, the GDP and French imports from the EU. However, the tests have not identified a causal effect on growth. Thus, further studies of Rodriguez and Rodrik (2000) covering a sample of 57 countries for the years 1970-1989. They exploited an empirical model completely specified to appreciate the channels linking trade policy and growth. Both authors stressed that the countries which make the choice of the opening are usually those who are better organized internally (political and macroeconomic stability, rule of law, good governance). The results suggest a positive effect of the policy of trade liberalization on growth, the accelerated accumulation of physical capital accounting for more than half the impact. ${ }^{8}$ In the same order of idea, Dollar and Kraay (2004) are based on a sample of 100 countries during 1980 and 1990 to study the effects of openness on economic growth. According to Dollar and Kraay's the equations are estimated in first differences: the dependent variable is the variation of the logarithm of the income per capita. To eliminate the fixed effects, the explanatory variables are the lagged variations of the same income during the previous decade and the rate of opening. The authors estimated that a doubling of the share of trade in GDP would result by a supplement of $25 \%$ of income at the end of 10 years. Using a panel of 47 developing countries between 1980 and 1997, Abdejabbar and Hanchane (2004) empirically tested the impact of a policy of openness on economic growth. For this, they have specified a dynamic model, by appealing to methods of appropriate estimations. This model with correlated random individual effect is estimated by various methods, including the generalized method of moments (GMM). They used several indicators that can more fully represent different dimensions of openness: exports, imports from poor countries and rich countries and FDI. Abdejabbar and Hanchane found that the coefficients attached to variables representing openness are always positive and significant. We can mention also, the study of Naoufel (2005) which estimates the impact of trade openness on growth through a dynamic panel of twelve countries in the Middle East and North Africa over the period 1963-2002. She gets that trade openness, measured by the ratio of exports to GDP, the ratio of imports to GDP and then the trade opening rate, on the logarithm of per capita GDP is positive and significant at $1 \%$. The study Galimberti (2009) is a re-evaluation of the hypothesis of export-led growth. The variables are used by Galimberti are the GDP per capita, the stock of human capital and the share of exports in GDP. In this context, the author uses a

\footnotetext{
8 The estimated model shows a beneficial overall effect of trade openness on growth, an increase of 8.5 percent of the measure of trade openness is associated with an increase of 0.601 per cent annual growth rate of once every channels of influence are considered.
} 
technique introduced by Hansen (1996, 1999 and 2000) to estimate the effect in threshold panel. This technique is applied in the cross-country regression studies covering a wide sample of 72 countries over the period 1974-2003. In general, the author considers that a situation of free trade as a result of increased exports will support growth.

In summary, a wide range of empirical studies $^{9}$ differ from each other student relationship integration and economic growth often come to the same basic conclusion, that is to say, to demonstrate a positive impact of openness on growth. In other words, conversely to the theoretical work and by proceeding to various methods of estimations, the obtained results are homogeneous and show a positive effect of openness on growth. However, if the results of this work are able to demonstrate a positive impact of integration on growth, their robustness (sensitivity) is called into question, for two main reasons. The first is related to the choice of indicator of integration "proxy". The second refers to the econometric methods used do not allow to control in a rigorous way bias related to unobserved individual heterogeneity of the countries.

\section{The modalities of regional integration}

Since the middle of the $80 \mathrm{~s},{ }^{10}$ regional integration knows a considerable revival. It is obvious that the emergence of regional groupings have an important role in the growth of international trade. In this respect, we observe at the moment the constitution of large blocks and regional sets of great dimension (reactivation of the Andean Pact at the end of 1991, come into effect of the NAFTA in 1994, project of free trade area of Americas (FTAA), enlargement of the EU, creation of Mercosur, etc.). This section aims to present the evolution of some experiences in regional integration. Among the experiences of integration, the EU is the model of economic integration the most successful. In the same order of idea, Balassa (1961) identified a distinction between the five stages of economic integration, namely the free trade area; the customs union; the common market; the economic union, and the complete economic integration (or total fusion). This pattern of regional integration has long emerged as the archetype of the regionalization process, confirmed for a long time by the example of European integration.

The motivation for almost all of the experiences of economic integration was the prospect of enhanced economic growth. Its success will improve competition, reduce transaction costs, allow economies of scale, attract FDI and facilitate macroeconomic coordination, etc. The effects of economic integration can be approached from two perspectives, namely the effects of static and dynamic effects. The static effects are mainly in terms of productive efficiency and consumer welfare, while the dynamic effects relate to the long-term growth rates of member countries. Combined, these effects determine the welfare gains associated with

\footnotetext{
9 See Appendix (Table 8): Summary of empirical studies on the effects of economic integration on growth.

${ }^{10}$ With the exception of the European experience.
} 
economic integration. First, the static effects of economic integration are related to production efficiency and well-being of consumers. We can observe static effects on welfare when the tariff barriers of the member countries of a trade bloc fall. In this context, member countries will eliminate all tariff restrictions between them, while maintaining a common tariff policy against non-members and harmonize their economic policies. In this case, prices will naturally fall, and it favors the static effects. In terms of static effects, the movement towards trade liberalization will affect the welfare of the countries in two ways: ${ }^{11}$ the trade creation effect and trade diversion effect. Second, the dynamic effects influence the rate of long-term growth of member countries. This is supported by a set of mechanisms such as: the extension of the markets allowing of the economies of scale, increased foreign investment, increasing competition between countries and greater specialization of these countries for better allocation of resources, etc.

\section{Variables presentations and the econometric model}

The present study covers the period from 1970 to 2009 and concerns a panel of 40 countries both developed and developing. ${ }^{12}$ In this article we will estimate in the first part a linear model of panel data. In the second part we integrate dummies variables in our estimation to better understand the impact of integration. This empirical work is part of the studies seeking to identify the effects of openness and integration on economic growth. This section will focus primarily on the description of the empirical methodology adopted: it is a question of presenting the model to estimate, the sample of countries and estimation technique. Secondly, we will finish by the interpretation of results provided by the estimation of our model.

\section{Empirical Methodology}

To answer our problem empirically, we use the following model that addresses the impact of economic integration measured by the degree of trade openness, FDI, R\&D and dummies variables. However, economic growth (GDP) is the dependent variable in the model is explained by other control variables as defined by classical theory as follows: human capital (HC), the inflation rate (INF) public consumption (PUBC) and domestic investment (GFCF). ${ }^{13}$ Since our sample includes countries not integrated, we developed a dummy variable that takes the value 0 if the country is not integrated and 1 if not. Thus, countries selected to present different degree of integration. This will be indexed by a variable score of $0-6$ otherwise of country not

\footnotetext{
11 To determine the net effects of integration on welfare, we must compare the effects of creating trade with the diversion effects. If the effects of diversion are more important than the effects of creation, there is a possibility that integration would lead to a reduction in economic welfare of the importing country. On the other hand, if the effects of development are more important than the effects of diversion, there is a net increase in economic welfare of the importing country. The balance between trade creation and trade diversion is an important determinant of the overall global benefits of a RIA.

12 See the list of the countries in the Appendix (Table 9).

13 See Appendix (Table 10).
} 
Table 1 Various stages of economic integration

\begin{tabular}{|c|c|c|c|c|c|c|}
\hline \multirow[t]{2}{*}{ Stage } & \multirow[t]{2}{*}{ Specificity } & \multicolumn{5}{|c|}{ Some experiments of REI } \\
\hline & & EU & MERCOSUR & ASEAN & NAFTA & CER \\
\hline $\begin{array}{l}\text { Agreement } \\
\text { of free } \\
\text { trade(AFT) }\end{array}$ & $\begin{array}{l}\text {-Abolition of the customs duties on } \\
\text { products native of member } \\
\text { countries. } \\
\text {-Autonomous outside economic } \\
\text { policy vis-à-vis third countries. } \\
\text {-Rules of origin and necessary } \\
\text { customs controls. } \\
\Longrightarrow \text { No tariff between the Member } \\
\text { States and reduction of the } \\
\text { nontariff barriers. }\end{array}$ & $X$ & $X$ & $X$ & $X$ & $X$ \\
\hline $\begin{array}{l}\text { Customs } \\
\text { union (CU) }\end{array}$ & $\begin{array}{l}\text {-Suppression of tariffs on products } \\
\text { originating in member countries. } \\
\text {-Common external tariff vis-à-vis } \\
\text { third countries. } \\
\text {-Rules of origin and customs controls } \\
\text { superfluous. } \\
\Longrightarrow \text { CU }=\text { AFT + Common External } \\
\text { Tariff }(\mathrm{CET}) .\end{array}$ & $\mathrm{X}$ & $\mathrm{X}$ & & & \\
\hline $\begin{array}{l}\text { The } \\
\text { Common } \\
\text { Market } \\
\text { (CM) }\end{array}$ & $\begin{array}{l}\text { In addition to the free movement of } \\
\text { goods, the market provides the } \\
\text { mobility of production factors } \\
\text { (labor and capital). } \\
\Rightarrow \mathrm{CM}=\mathrm{CU}+\text { free mobility of } \\
\text { people }\end{array}$ & $X$ & $\mathrm{X}$ & & & \\
\hline $\begin{array}{l}\text { Economic } \\
\text { union (EU) }\end{array}$ & $\begin{array}{l}\text {-Single Market inside which people, } \\
\text { goods, services and capital can } \\
\text { circulate freely. } \\
\text {-Competition policy and other } \\
\text { measures to strengthen market } \\
\text { mechanisms. } \\
\text { Common policy aiming at the } \\
\text { structural adjustment and regional } \\
\text { development. } \\
\text {-Coordination of economic policies. } \\
\Longrightarrow \text { EU = CM + policy } \\
\text { harmonization }\end{array}$ & $X$ & & & & \\
\hline $\begin{array}{l}\text { Complete } \\
\text { economic } \\
\text { Integration } \\
\text { (CEI) }\end{array}$ & $\begin{array}{l}\text {-Guarantee of a total and irreversible } \\
\text { convertibility of currencies } \\
\text { between them; } \\
\text {-complete liberation movement of } \\
\text { the movements of capital and } \\
\text { complete integration of the banking } \\
\text { markets and other financial } \\
\text { markets. } \\
\text {-Elimination of fluctuation margins } \\
\text { and irrevocable fixing of parities. } \\
\Longrightarrow \text { IEC = MU + common } \\
\text { monetary policy }\end{array}$ & $X$ & & & & \\
\hline
\end{tabular}

Source: Synthesis of the author 
integrated up to countries the most integrated. To do this, we will estimate the following regression:

$$
\begin{aligned}
G D P_{i, t}= & \alpha_{0}+\alpha_{1} \text { OPEN }_{i, t}+\alpha_{2} F D I_{i, t}+\alpha_{3} \mathrm{R}_{2} D_{i, t}+\alpha_{4} H C_{i, t}++\alpha_{5} G F C F_{i, t}+\alpha_{6} I_{i, t} F_{i, t} \\
& +\alpha_{7} \text { PUBC }_{i, t}+\alpha_{8} \text { Integ }_{i, t}+\alpha_{9} \text { DegInteg }_{i, t}+U_{i, t}
\end{aligned}
$$

With: i denote country and tenotes time (year).

$G D P_{i, t}$ : The logarithm of gross domestic product, a variable that reflects the level of development of a country which is an indicator of growth.

$F D I_{i, t}$ : Foreign direct investment (percent of GDP).

$H C_{i, t}$ : Human capital is proxied by secondary school enrollment.

$O P E N_{i, t}$ : The level of trade openness approximated by the report.

$G F C F_{i, t}$ : The gross fixed capital formation (percent of GDP).

$\mathrm{R} \& D_{i, t}$ : Expenditure on R\&D (percentage of GDP).

$I N F_{i, t}$ : The inflation rate measured by the GDP deflator.

$P U B C_{i, t}$ : Public consumption (percentage of GDP).

Integ $_{i, t}$ : Dummy variable takes the value 1 when there is integration in any type of regional groupings, 0 otherwise.

DegInteg $_{i, t}$ : This variable can take values from 0 (no integration agreement) to 6 (full economic integration).

$U_{i, t}$ : The error term.

\section{Data and Samples}

Our work involves a heterogeneous sample consisting of two groups of countries. It is formed by 20 emerging countries and 20 developed countries. The choice of these countries due to the fact that the group of developed countries is considered the most advanced in terms of the integration process. Thus, the emerging countries that have attempted to integrate into the international economy and benefit in terms of economic growth. The period is spread out from 1970 to 2009 depending on availability of data, calculated on average over eight sub period of 5 years each one (Table 1).

The descriptive statistics

Table 2 reveals that the average economic growth rate of the sample over the study period was $2.293 \%$. The minimum average growth rate recorded is recorded in Egypt $(-14.32 \%)$, while the maximum is in Venezuela $(23.62 \%)$. With regard to indicators of economic integration, the Philippines recorded the maximum values for the degree of openness $(438.09 \%)$. In addition to the average open rate of the sample is quite large $(65.74 \%)$ during the period studied this is explained by the trade liberalization policies adopted by these various countries. The entering FDI highest are recorded in Belgium (92.49\%). On the other hand Ireland recorded the lowest value $(-15.048 \%)$. The R\&D in turn, has an average rate of about $1.41 \%$ and Sweden has the maximum value for R \& D expenditures ( $\%$ of GDP). 
Table 2 Descriptive statistics

\begin{tabular}{lcccc}
\hline Variable & Mean & Ecart-type & Min & Max \\
\hline TCR & 2.293393 & 3.502158 & -14.32095 & 23.62967 \\
OPEN & 65.74372 & 56.33768 & 9.1023 & 438.0917 \\
FDI & 2.093292 & 4.178093 & -15.0483 & 92.49893 \\
GFCF & 22.79905 & 5.368398 & 11.15962 & 48.58504 \\
RD & 1.412465 & 1.001987 & 0.0475633 & 4.238408 \\
\hline
\end{tabular}

From Table 3, we see that the growth rate of the GDP of the not integrated countries $(2.32 \%)$ is slightly higher than those of the integrated countries (2.26). On the other hand, the commercial opening rate in the integrated countries is higher than that of other countries ( $81 \%$ against $52 \%$ ) the latter benefit from the removal of barriers to trade, the abolition of customs duties and the principle of Community preference. Concerning, the entering FDI the integrated countries are rather significant $(3.099 \%)$ almost three times that of non-integrated countries $(1.043 \%)$. Economic integration usually results in the elimination of customs barriers and lower transportation costs for the various markets of integrated area. This makes the region more attractive for FDI. In addition, integration can foster the development of cooperation between states and companies in member countries, particularly in the crucial field of the research and development. In this context, also that spending on research and development in the integrated countries (1.619\%) is twice as large as that of not integrated countries $(0.82 \%)$.

Regarding the correlation between variables (see Table 4), two observations deserve to be made. First, there is a positive and significant correlation to the threshold of $5 \%$ between the variable which explains economic integration (opening rate) and the economic growth rate. There is also a strong correlation, which is positive and significant, between indicators of economic integration (open rates, FDI and $\mathrm{R} \& \mathrm{D}$ ). As for the opening rate, it is positively correlated with the rate of economic growth, FDI and HC. However, it is negatively correlated with the GFCF and the expenditure in R\&D. It can be argued that the expected results will be in the same direction that is to say a positive effect of openness on economic growth Table 4.

The following analysis focuses on the one hand to the empirical evaluation of the impact of economic integration on economic growth and also to highlight the effect of economic integration on FDI and expenditure on R\&D. To do this, an analysis is performed in a panel to make findings of long-term.

\section{Estimation Method}

The use of the panel estimation techniques allows taking consideration of the specific temporal and transverse of this sample. The panel estimation with fixed effects introduces several advantages, especially related to the inclusion of the unobservable and stable characteristics over time. First, this technique produces more variability, more degrees of freedom, and more efficiency and minimizes the 


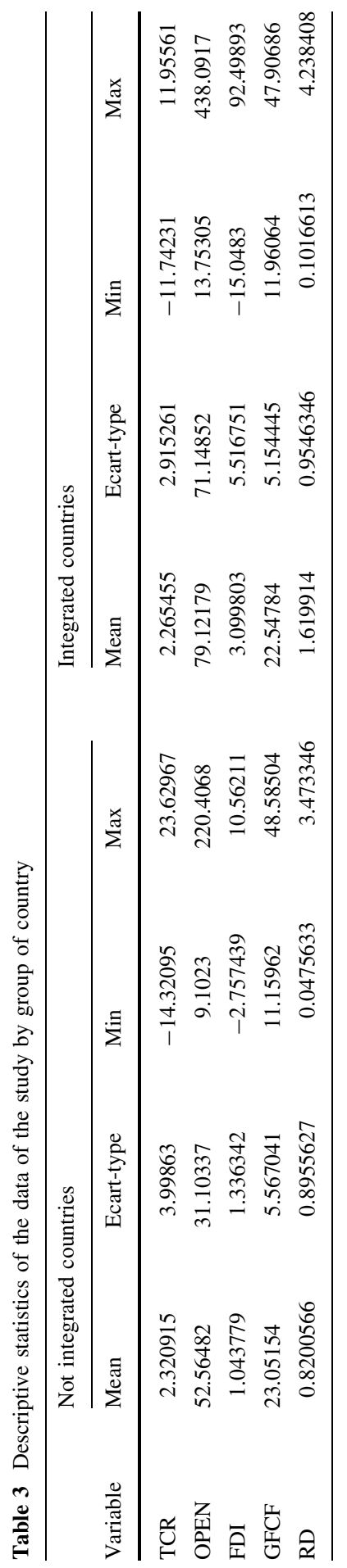


Table 4 Correlations between the variables

\begin{tabular}{|c|c|c|c|c|c|c|c|c|}
\hline & 1 & 2 & 3 & 4 & 5 & 6 & 7 & 8 \\
\hline $1 \mathrm{GDP}$ & 1 & & & & & & & \\
\hline 2 OPEN & $0.1456^{*}$ & 1 & & & & & & \\
\hline 3 FDI & 0.0113 & $0.1031 *$ & 1 & & & & & \\
\hline $4 \mathrm{R} \& \mathrm{D}$ & -0.0168 & 0.0927 & $0.1101 *$ & 1 & & & & \\
\hline $5 \mathrm{GFCF}$ & $0.1364 *$ & -0.0141 & $0.0673^{*}$ & 0.0227 & 1 & & & \\
\hline $6 \mathrm{HC}$ & -0.0336 & $-0.1567 *$ & -0.0288 & $-0.2907 *$ & $-0.3879 *$ & 1 & & \\
\hline 7 PUBC & $-0.1363^{*}$ & $-0.3550^{*}$ & -0.0275 & -0.0481 & $-0.1098^{*}$ & $0.2069 *$ & 1 & \\
\hline 8 INF & $-0.1683^{*}$ & $-0.0786^{*}$ & -0.0344 & $-0.3030 *$ & -0.0425 & $0.1515^{*}$ & $0.0951 *$ & 1 \\
\hline
\end{tabular}

* Significant at $5 \%$ level

risk of multicollinearity between the explanatory variables. Second, it treats the problem of potential correlation between some explanatory variables and the error term that does not vary over time. Third, the fixed effects model exploits the temporal dimension of data and allows taking into account the dynamics of adjustment. Fourth, control heterogeneity by the inclusion of the invariant characteristics in time and/or space. We use the Hausman test which allows choosing between the specific fixed and random effects. The results of the Hausman test shows that in most of the regressions fixed effects model is most relevant. Then, by incorporating dummy variables in our model to better address the phenomenon of economic integration and economic growth.

\section{Results}

The following development presents our econometric results and their statistical and economic interpretations. The results of the estimated model appear in the Tables (5) and (6).

Empirical estimates show a positive effect of key variables of economic integration on the growth of member countries. The coefficients of the explanatory variables (open rates, FDI and R\&D) are positive and significant in almost all the table columns (5 and 6). This implies that economic integration has a positive and significant effect on growth. However, this positive effect is relatively diminished by introducing these variables simultaneously. In this context, our results confirm those of other studies that have confirmed the positive effect of openness on growth. Indeed, Dollar and Kraay (2004) studied the effects of openness on economic growth for a sample of 100 countries for the years 1980 and 1990. They concluded the existence of a positive and significant relationship between openness and growth.

Introducing FDI in the regression, we find that the coefficients of FDI and openness are positive and significant for both estimates. This means that the two variables act simultaneously on economic growth. This result supports the idea that integration by the opening and the abolition of the commercial obstacles constitutes a source of attractiveness of FDI. The entry of other variables in the regression does not affect the significance of FDI. The introduction of these variables slightly 


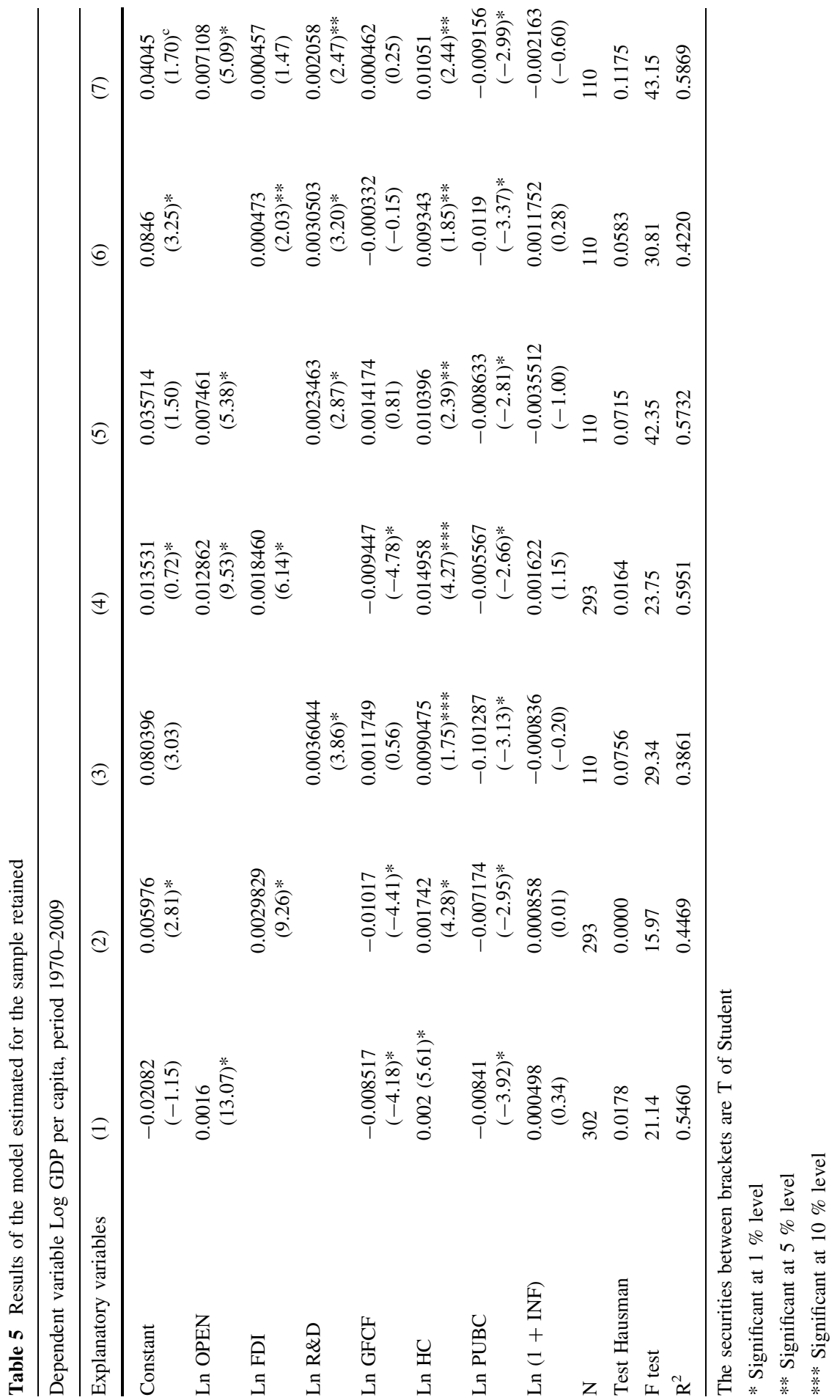




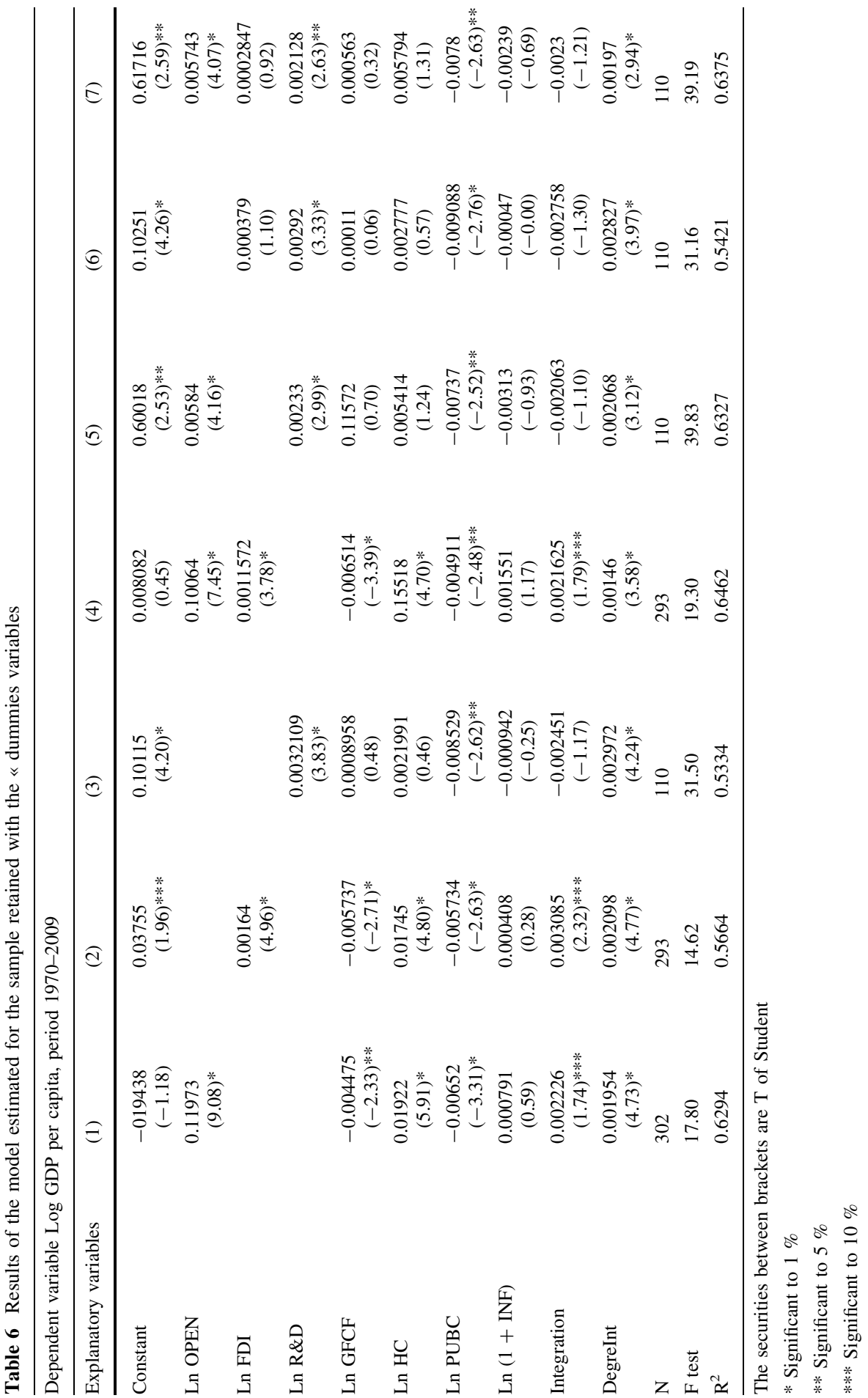


reduces the significance of FDI. Several empirical studies that have examined the effects of FDI have affirmed the existence of positive impact of FDI on growth. Indeed, Bengoa and Sanchez-Robles (2003) studied the link between openness, the FDI and economic growth using panel data for a sample of 18 Latin American countries for the period 1970-1999. Their results show that openness and economic integration of countries is a precondition for attracting FDI and consequently the improvement of the economic growth.

Another example is the work of Darrat et al. (2005) as an example of this approach. These authors tested the effects of FDI on economic growth. Their work focuses on a sample of 23 countries in the EEC and the MENA during the period (1979-2002). The main result of this study is that FDI stimulates economic growth only in the candidate countries to the EU. The explanation is that the two authors to join the EU there is a wider application and effectiveness of the reforms, which would have contributed to the creation of positive effect of FDI flows on economic growth. These results suggest the crucial role played by economic integration in increased flows of FDI and hence economic growth.

In the same order of idea, the coefficients of the expenditure of $R \& D$ are positive and significant implying that this variable promotes growth. The same is also observed for the second sample. At this point our results confirm other studies that have reported empirically the importance of R\&D for the growth. Indeed, Robert and Kwinder (1997) used panel data for eleven Asian countries over the period 1970-1993 to test the effect of R\&D on growth. The main result of this study is that R\&D has positive and significant effects on the growth in GDP of Asian countries.

Concerning GFCF, for both samples, the coefficients of this variable is highly significant and positive. The first and the third column of the first table show a high significance of GFCF. Generally, the opening and/or economic integration increases and motivate GFCF. The entry of other variables in the regression does not affect the significance of GFCF. The introduction of FDI and R\&D in the regression reduces the coefficient of GFCF whereas this last significant remainder with the other variables. The positive effect of openness and economic integration on domestic investment is manifested through several channels. Among these channels, the increase of the competition and the efficiency, the transmission of the techniques of control and quality to the entrepreneurs and the introduction of a new skill. MNCs can also push local firms to improve their management or to adopt some of the marketing techniques used by multinational companies or the local market or internationally. Markusen and Venables (1999) consider that there are possible effects of complementarity between openness and domestic investment although this effect is indirect. The openness and economic integration can increase the number of foreign companies which stimulates domestic investment provided the necessary training effects are created.

Some work, such as Coe et al. (1997), Edwards (1998), suggest that to take advantage of the opening, countries must have a skilled workforce, that is, that human capital capable of assimilating foreign technology. In the same way, it has been recognized since work of Findlay (1978) and Lucas (1988) that the HC plays an important role in economic growth. When the $\mathrm{HC}$ level is high, it allows 
domestic firms to easily understand the technical configurations of technologies adopted by foreign firms and therefore facilitates the processes of initiation and learning. In addition, it allows host countries to benefit from the mobility of work of foreign companies to domestic companies. On the effects of human capital, estimates show that the coefficient of the latter is positive and significant in both tables. Following the introduction of other variables (FDI, labor force and stock of $\mathrm{R} \& \mathrm{D})$ in the regression there is a loss of significance and positive sign of HC. This cannot neglect the role of human capital as an important factor in the growth and development. The presence of a qualified labor makes it possible to participate and/ or further economic integration between the various parties.

In conclusion, in this section, we empirically tested the impact of different indicators of integration (the degree of openness, FDI and R\&D and dummies variables) on economic growth. Our work is based on a sample of 40 countries (20 emerging countries and 20 OECD countries) for the periods 1970-2009. As a result, we presented the econometric methodology adopted to estimate our model. The main results are as follows: the coefficients attached to variables representing openness are in most cases positive and significant in both tables. Similarly, there is a significant positive effect of FDI and R\&D on economic growth of member countries of the two samples. These results confirm the hypothesis that economic integration allows different parties to access knowledge and foreign knowledge.

\section{Conclusion}

Empirically, the aim of this study was to determine how and to what extent regional economic integration affects growth. For this, we used panel data on a sample of 40 countries during the period 1970-2009. The main results and any consequent recommendations are: Economic integration is not simply a question of potential profits and balance between the benefits and costs. It involves national economic strategies that have ramifications. Overall, this work can be concluded that the implementation of a policy of openness with an integration process must be at the heart of public intervention to promote growth and improve social welfare. At this point, the greatest achievements in regional integration have been achieved by the EU, mainly because the integration is both deeper and wider in the region. Individual countries need to learn, adopt and incorporate the lessons of trade reforms in the industry of the country, in order to reap the benefits of integration and liberalization process. However, this does not mean that these countries should adopt the European model as a standard. Countries should take the lead in setting priorities for an economic agenda. The main priorities should be the elimination of tariff and nontariff barriers and harmonization of markets between the different members. These priorities will help to focus on concrete and achievable projects.

Finally, it should be noted that this work presents a modest contribution that could be improved in several directions. The results found depend of course on the methodology and data used. However, other variables can better help understand the importance of openness and integration more generally on economic growth. These 
variables include political stability, distance, property rights, taxation, corruption, etc. A more detailed study would require the consideration of these variables.

\section{Appendix}

See Tables 7, 8, 9 and 10

Table 7 Theoretical contribution of regional integration

\begin{tabular}{|c|c|c|}
\hline & Theories & Conception or Theoretical Argumentation \\
\hline \multirow[t]{5}{*}{$\begin{array}{l}\text { Theories of } \\
\text { international } \\
\text { trade }\end{array}$} & $\begin{array}{l}\text { The theory of absolute and } \\
\text { comparative advantages }\end{array}$ & $\begin{array}{l}\text { According to Smith and Ricardo, participation in } \\
\text { international trade allows an optimal allocation } \\
\text { of productive resources between countries and } \\
\text { inside even of each country since this last will } \\
\text { direct its factors of production towards the most } \\
\text { effective sectors }\end{array}$ \\
\hline & HOS & $\begin{array}{l}\text { The HOS model based on the international } \\
\text { exchange of differences in relative endowments } \\
\text { of factors. This model is often considered as } \\
\text { adopted in the study of trade integration } \\
\text { between countries }\end{array}$ \\
\hline & $\begin{array}{l}\text { The theory of customs unions } \\
\text { Viner (1950) and Meade } \\
\text { (1955) }\end{array}$ & $\begin{array}{l}\text { The effects of integration are evaluated using the } \\
\text { concepts of creation and trade diversion. It } \\
\text { focuses on the effects of consumption resulting } \\
\text { from the formation of a customs union or free } \\
\text { trade area (FTA) }\end{array}$ \\
\hline & $\begin{array}{l}\text { The theory of optimum currency } \\
\text { areas Mundell (1957) }\end{array}$ & $\begin{array}{l}\text { This theory attempts to assess the appropriateness } \\
\text { of the monetary union between countries. } \\
\text { Monetary union is expected to produce } \\
\text { economic benefits, such as the elimination of } \\
\text { transaction costs }\end{array}$ \\
\hline & $\begin{array}{l}\text { The theory of fiscal federalism: } \\
\text { Oates (1972) and King (1984) }\end{array}$ & $\begin{array}{l}\text { It deals with issues related to taxation and the } \\
\text { coordination of fiscal policies in a set of } \\
\text { associated states }\end{array}$ \\
\hline \multirow[t]{3}{*}{$\begin{array}{l}\text { Theories of } \\
\text { economic } \\
\text { geography }\end{array}$} & $\begin{array}{l}\text { Paul Krugman's model: the } \\
\text { model "center-periphery" }\end{array}$ & $\begin{array}{l}\text {-The global economy was supposed to be } \\
\text { organized in blocks of commerce or trade equal } \\
\text { in economic size, with a free trade zone in each } \\
\text { block }\end{array}$ \\
\hline & & $\begin{array}{l}\text {-The blocks were supposed to charge tariffs or } \\
\text { non-cooperative price to maximize welfare }\end{array}$ \\
\hline & The model of Venables & $\begin{array}{l}\text { Venables generalizes a business model similar to } \\
\text { the thesis of Hechscher-Ohlin model to assess } \\
\text { the impact of an FTA on income countries } \\
\text { relative to their initial endowments of factors }\end{array}$ \\
\hline
\end{tabular}


Table 7 continued

\begin{tabular}{|c|c|c|}
\hline & Theories & Conception or Theoretical Argumentation \\
\hline & The model of Richard Baldwin & $\begin{array}{l}\text { Baldwin spent the bulk of its work to European } \\
\text { integration. In addition, Baldwin }(1989,1992) \\
\text { in a major analytical study of the effects of an } \\
\text { investment in AIR, postulates a positive effect } \\
\text { of investment from the European single market } \\
\text { (Shiff and Winters 2003) }\end{array}$ \\
\hline $\begin{array}{l}\text { Gravitational } \\
\text { models }\end{array}$ & \multicolumn{2}{|c|}{$\begin{array}{l}\text { This model explains in a satisfactory way the flow of bilateral trade, positively by the } \\
\text { importance of the size of the economies partners, and negatively by the } \\
\text { geographical distance separating them, this distance being retained like proxy of } \\
\text { transportation costs, Tinbergen (1962) and Pöyhönen (1963) }\end{array}$} \\
\hline $\begin{array}{l}\text { Symmetrical } \\
\text { models }\end{array}$ & \multicolumn{2}{|c|}{$\begin{array}{l}\text { Bond and Syropoulos (1996) have introduced the factor of comparative advantage, in } \\
\text { a masterly manner to analyze the phenomenon of regionalization, according to their } \\
\text { theoretical conception each country an equal endowment in all goods, plus an } \\
\text { additional quantity (positive or negative) of one of them }\end{array}$} \\
\hline
\end{tabular}

Table 8 Summary of empirical work on the effects of economic integration on growth

\begin{tabular}{|c|c|c|c|c|}
\hline \multicolumn{5}{|c|}{ Empirical studies of the effects of economic integration on growth } \\
\hline Studies & Countries & Years & Integration variable & Conclusions \\
\hline Feder (1983) & $\begin{array}{l}31 \text { semi- } \\
\text { industrialized } \\
\text { countries }\end{array}$ & $1960-1973$ & $\begin{array}{l}\text { Growth of exports } \\
\text { weighted by the share } \\
\text { of exports }\end{array}$ & $\begin{array}{l}\text { A positive relationship } \\
\text { between GDP growth } \\
\text { and export growth }\end{array}$ \\
\hline $\begin{array}{l}\text { Brada and } \\
\text { Mendez } \\
1988)\end{array}$ & The EEC & $1951-1977$ & Dummies: membership & $\begin{array}{l}\text { The membership of the } \\
\text { EEC is positively } \\
\text { related to investment } \\
\text { but not independently to } \\
\text { growth }\end{array}$ \\
\hline $\begin{array}{l}\text { Romer } \\
(1990)\end{array}$ & 112 countries & $1960-1985$ & $\begin{array}{l}\text { Growth rate of export } \\
\text { volume growth }\end{array}$ & $\begin{array}{l}\text { Rate of exports volume } \\
\text { growth accelerates } \\
\text { technological progress } \\
\text { and creates a direct } \\
\text { effect on the growth of } \\
\text { per capita income }\end{array}$ \\
\hline $\begin{array}{l}\text { Landau } \\
\text { (1995) }\end{array}$ & $\begin{array}{l}17 \text { countries of } \\
\text { OECD }\end{array}$ & $1950-1990$ & $\begin{array}{l}\text { Dummies: membership in } \\
\text { the EU }\end{array}$ & $\begin{array}{l}\text { No significant effect of } \\
\text { integration on growth }\end{array}$ \\
\hline $\begin{array}{l}\text { Coe and } \\
\text { Helpman } \\
(1995)\end{array}$ & $\begin{array}{l}22 \text { countries of } \\
\text { OECD }\end{array}$ & $1974-1990$ & Capital stock of R\&D & $\begin{array}{l}\text { The positive effect of } \\
\text { foreign R\&D on TFP }\end{array}$ \\
\hline $\begin{array}{l}\text { Sachs and } \\
\text { Warner } \\
(1995)\end{array}$ & 122 countries & 1970-1989 & $\begin{array}{l}\text { Index opened/closed on } \\
\text { the basis of five criteria }\end{array}$ & $\begin{array}{l}\text { Open countries grow } \\
\text { faster than closed } \\
\text { countries. }\end{array}$ \\
\hline $\begin{array}{l}\text { Henrekson } \\
\text { et al. } \\
\text { (1997) }\end{array}$ & $\begin{array}{l}\text { All OECD } \\
\text { countries and } \\
\text { some } \\
\text { neighboring } \\
\text { countries }\end{array}$ & 1976-1985 & $\begin{array}{l}\text { Dummies member of the } \\
\text { EC/EFTA }\end{array}$ & $\begin{array}{l}\text { Membership in the EC } \\
\text { and/or EFTA enhances } \\
\text { growth }\end{array}$ \\
\hline
\end{tabular}


Table 8 continued

Empirical studies of the effects of economic integration on growth

\begin{tabular}{|c|c|c|c|c|}
\hline Studies & Countries & Years & Integration variable & Conclusions \\
\hline $\begin{array}{l}\text { Haveman } \\
\text { et al. } \\
\text { (1998) }\end{array}$ & $\begin{array}{l}74 \text { different } \\
\text { countries }\end{array}$ & 1970-1989 & Opening rate and FDI & $\begin{array}{l}\text { The opening rate and FDI } \\
\text { exert a positive and } \\
\text { significant effect on } \\
\text { growth }\end{array}$ \\
\hline $\begin{array}{l}\text { Vanhoudt } \\
\text { (1999) }\end{array}$ & $\begin{array}{l}23 \text { countries of } \\
\text { OECD }\end{array}$ & 1950-1990 & $\begin{array}{l}\text { Dummies: membership in } \\
\text { the EU }\end{array}$ & $\begin{array}{l}\text { Membership in the EU } \\
\text { has not had a significant } \\
\text { effect on the growth of } \\
\text { members }\end{array}$ \\
\hline $\begin{array}{l}\text { Frankel and } \\
\text { Romer } \\
\text { (1999) }\end{array}$ & 150 countries & 1982-1995 & $\begin{array}{l}\text { Rates of opening rest } \\
\text { some on instrumental } \\
\text { variables including the } \\
\text { geographical } \\
\text { characteristics of the } \\
\text { countries }\end{array}$ & $\begin{array}{l}\text { International trade has an } \\
\text { important and } \\
\text { significant impact on } \\
\text { growth }\end{array}$ \\
\hline $\begin{array}{l}\text { Rodriguez } \\
\text { and Rodrik } \\
(2000)\end{array}$ & 57 countries & 1970-1989 & Trade openness & $\begin{array}{l}\text { A total beneficial effect of } \\
\text { trade openness on } \\
\text { growth }\end{array}$ \\
\hline $\begin{array}{l}\text { Guillaumont } \\
\text { (2002) }\end{array}$ & $\begin{array}{l}\text { Member } \\
\text { countries of } \\
\text { the EU and } \\
\text { France }\end{array}$ & $\begin{array}{l}1854-1913 \\
\text { and } \\
1957-1999\end{array}$ & Trade & $\begin{array}{l}\text { The tests of Co- } \\
\text { integration showed that } \\
\text { there is a relation of } \\
\text { long term between the } \\
\text { French exchanges } \\
\text { towards the UE and the } \\
\text { GDP. However, the } \\
\text { tests of causalities did } \\
\text { not release a negotiable } \\
\text { instrument on the } \\
\text { growth }\end{array}$ \\
\hline $\begin{array}{l}\text { Bengoa and } \\
\text { Sanchez- } \\
\text { Robles } \\
(2003)\end{array}$ & $\begin{array}{l}18 \text { Latin } \\
\text { American } \\
\text { countries }\end{array}$ & 1970-1999 & Opening rate and FDI & $\begin{array}{l}\text { Openness and economic } \\
\text { integration of countries } \\
\text { is a precondition for } \\
\text { attracting FDI and } \\
\text { hence improving } \\
\text { economic growth }\end{array}$ \\
\hline $\begin{array}{l}\text { Dollar and } \\
\text { Kraay } \\
(2004)\end{array}$ & 100 countries & 1980-1990 & Opening rate & $\begin{array}{l}\text { A positive and significant } \\
\text { relationship between } \\
\text { trade openness and } \\
\text { economic growth }\end{array}$ \\
\hline $\begin{array}{l}\text { Abdejabbar } \\
\text { and } \\
\text { Hanchane } \\
\text { (2004) }\end{array}$ & $\begin{array}{l}47 \text { developing } \\
\text { countries }\end{array}$ & 1980-1997 & Exports, imports and FDI & $\begin{array}{l}\text { The coefficients attached } \\
\text { to variables } \\
\text { representing openness } \\
\text { are always positive and } \\
\text { significant }\end{array}$ \\
\hline $\begin{array}{r}\text { Naoufel } \\
(2005)\end{array}$ & $\begin{array}{r}12 \text { MENA } \\
\text { countries }\end{array}$ & 1963-2002 & $\begin{array}{l}\text { The ratio of exports to } \\
\text { GDP, the ratio of } \\
\text { imports to GDP, then } \\
\text { the rate of commercial } \\
\text { openness }\end{array}$ & $\begin{array}{l}\text { Positive and significant } \\
\text { effect on economic } \\
\text { growth }\end{array}$ \\
\hline
\end{tabular}


Table 8 continued

Empirical studies of the effects of economic integration on growth

\begin{tabular}{|c|c|c|c|c|}
\hline Studies & Countries & Years & Integration variable & Conclusions \\
\hline $\begin{array}{l}\text { Darrat et al. } \\
\text { (2005) }\end{array}$ & $\begin{array}{l}23 \text { countries in } \\
\text { the EEC and } \\
\text { the MENA }\end{array}$ & 1979-2002 & FDI & $\begin{array}{l}\text { FDI stimulates economic } \\
\text { growth only in the } \\
\text { candidate countries for } \\
\text { EU }\end{array}$ \\
\hline $\begin{array}{l}\text { Galimberti } \\
(2009)\end{array}$ & 72 countries & 1974-2003 & $\begin{array}{l}\text { The share of exports in } \\
\text { GDP }\end{array}$ & $\begin{array}{l}\text { The variables determining } \\
\text { growth are statistically } \\
\text { significant }\end{array}$ \\
\hline
\end{tabular}

Table 9 Samples of the countries

\begin{tabular}{ll}
\hline Samples & Countries \\
\hline EU & $\begin{array}{c}\text { Austria, Belgium, Luxembourg, France, Germany, Italy, Netherlands, the United } \\
\text { Kingdom, Ireland, Spain, Finland, Denmark, Greece, Portugal and Sweden }\end{array}$ \\
NAFTA & USA, Canada and Mexico \\
MERCOSUR & Argentina, Brazil, Chile, Colombia, Venezuela and Peru \\
ASEAN & Japan, Singapore, Thailand, Philippine, Indonesia, R Korea and Singapore \\
CER & Australia and New-Zealand \\
Others & Norway, Algeria, Tunisia, Egypt, Pakistan, Turkey and Morocco \\
\hline
\end{tabular}

Table 10 Name and sources of the variables used

\begin{tabular}{|c|c|c|c|}
\hline & Variables & Définition & Source \\
\hline $\begin{array}{l}\text { Variables } \\
\text { dépendantes }\end{array}$ & GDP & Growth of PIB/tête & WDI (2009) \\
\hline \multirow[t]{9}{*}{$\begin{array}{l}\text { Variables } \\
\text { explicatives }\end{array}$} & OPEN & $\begin{array}{l}\text { Rate of opening: (Exportations + Importations)/ } \\
\text { PIB }\end{array}$ & WDI (2009) \\
\hline & INFL & Annual inflation rate & WDI (2009) \\
\hline & FDI & $\begin{array}{l}\text { Entering foreign direct investments (expressed as a } \\
\text { percentage of GDP) }\end{array}$ & $\begin{array}{l}\text { Global Development } \\
\text { Finance (2009) }\end{array}$ \\
\hline & $\mathrm{HC}$ & Rough rate of schooling at the secondary level & $\begin{array}{l}\text { WDI (2009), } \\
\text { UNESCO Statistical } \\
\text { Yearbooks }\end{array}$ \\
\hline & $\mathrm{FBCF}$ & $\begin{array}{l}\text { Gross fixed capital formation expressed as a } \\
\text { percentage GDP }\end{array}$ & WDI (2009) \\
\hline & $\mathrm{RD}$ & $\begin{array}{l}\text { Expenditure of Research and Development } \\
\text { expressed as a percentage of the GDP }\end{array}$ & WDI (2009) \\
\hline & CPUB & $\begin{array}{l}\text { Public consumption (expressed as a percentage of } \\
\text { GDP) }\end{array}$ & WDI (2009) \\
\hline & Integ & $\begin{array}{l}\text { Dummy variable, takes the value of } 1 \text { differently } \\
\text { when there is integration in any type of the } \\
\text { regional regroupings, } 0\end{array}$ & Calculation of author \\
\hline & Degintg & Level of integration on a scale from 0 to 6 & Calculation of author \\
\hline
\end{tabular}




\section{References}

Abdejabbar A, Hanchane S (2004) La dynamique de la Croissance Économique et de l'ouverture dans les Pays en Développement: quelques investigations empiriques à partir des données de Panel. Document de travail L.E.S.T-UMR6123

Balassa B (1961) The theory of economic integration. George Allen and Unwin, London

Baldwin R (1989) The growth effects of 1992. Econ Policy 9:247-281

Baldwin RE (1992) Measurable dynamic gains from trade. J Political Econ 100:162-174

Baldwin R, Venables A (1995) Regional economic integration. In: Grossman G, Rogoff K (eds) Handbook of International Economics, vol III, pp 1597-1644

Bengoa M, Sanchez-Robles B (2003) Foreign direct investment, economic freedom and growth: new evidence for latin America. Eur J Polit Econ 19:529-545

Bond EW, Syropoulos C (1996) The size of trading blocks: market power and world welfare effects. J Int Econ 40:411-438

Brada J, Mendez J (1988) Exchange rate risk, exchange rate regime and the volume of international trade. Kyklos 41:263-280

Carbaugh RJ (2004) International Economics, 9th edn. Australia, Thomas South-Western

Cheru F (2002) African Renaissance: Road maps to the Challenge of Globalisation Cape Town. New Africa Books/David Phillip

Coe DT, Helpman E (1995) International R\&D spillovers. Eur Econ Rev 39(5):859-887

Coe DT, Helpman E, Hoffmaister AW (1997) North-South R\&D spillovers. Econ J 107(1):134-149

Darrat AF, Kherfi S, Soliman S (2005) FDI and Economic Growth in CEE and MENA Countries: A Tale of Two Regions. Economic Research Forum. In: 12th Annual Conference, $19^{\text {th }}-21$ st December 2005, Cairo, Egypt

Dollar D, Kraay A (2004) Trade, Growth and Poverty. Econ J 114:22-49

Edwards S (1998) Openness, productivity and growth: What do we really know? Econ J 108:383-398

Feder G (1983) On exports and economic growth. J Develop Econ 12(1/2):59-73

Feenstra R (1990) Trade and Uneven Growth. National Bureau of Economic Research Working Paper: 3276, March, p 30

Findlay R (1978) Relative backwardness, direct foreign investment, and the transfer of technology: a simple dynamic model. Q J Econ 92(1):1-16

Frankel J, Romer P (1999) Does Trade Cause Growth? American Economic Review American Economic Association 89(3):379-399

Galimberti JK (2009) Conditioned export-led growth hypothesis: a panel threshold regressions approach. Federal University of Santa Catarina, Munich Personal RePEc Archive. Paper No. 13417, posted 15

Gehrels F (1957) Government debt as a generator of economic growth. Rev Econ Stat 39(2):183-192

Global Development Finance (2009) Database focuses on financial flows, trends in external debt, and other major financial indicators for developing countries. Includes over 200 time series indicators from 1970 to 2010, for most reporting countries

Grossman GM, Helpman E (1991) Trade, knowledge spillovers, and growth. Eur Econ Rev 35(2-3):517-526

Guillaumont P (2002) Ouverture, vulnérabilité et développement, dans Boudhiaf M, Siroën J-M, Ouverture et développement économique. Economica, Paris, pp 149-172

Hansen BE (1996) Inference when a nuisance parameter is not identified under the null hypothesis. Econometrica 64:413-430

Hansen BE (1999) Threshold effects in non-dynamic panels: estimation, testing, and inference. J Econom 93:345-368

Hansen BE (2000) Sample splitting and threshold estimation. Economica 68(3):575-603

Haveman JD, Lei V, Netz JS (1998) International integration and growth: a survey and empirical investigation. Papers 98-003, Purdue University, Krannert School of Management- Center for International Business Education and Research (CIBER)

Henrekson et al (1997) Growth effects of European integration. Eur Econ Rev 41:1537-57

Kabunda AM (2005) La problématique des zones d'intégration économique en Afrique face à la globalisation des marchés, Unikin

King D (1984) Fiscal tiers: the economics of multi-level Government. Allen \& Unwin, London

Krugman P (1981) International Trade and Income Distribution: A Reconsideration. NBER Working Papers 0356, National Bureau of Economic Research, Inc 
Krugman P (1991) Increasing returns and economic geography. J Political Econ 99:483-499

Krugman P (1995) Technology, Trade, and Factor Prices. NBER Working Papers 5355, National Bureau of Economic Research, Inc

Krugman P, Venables J (1995) The seamless world: a spatial model of international specialization. CEPR Discussion Papers 1230, C.E.P.R. Discussion Papers

Landau D (1995) The contribution of the European common market to the growth of its member countries: an empirical test. Weltwirtschaftliches Archiv 13(4):774-782

Naoufel L (2005) Ouverture et croissance économique dans les pays MENA, étude dynamique des effets des facteurs structurels et institutionnels

Lipsey RG (1957) The theory of customs unions: a general Survey. Econ J 60:496-513

Lipsey RG (1960) The relation between unemployment and the rate of change of money wage rates in the United Kingdom, 1862-1957: a further analysis. Economica XXVII (105):1-32

Lucas R (1988) On the mechanics of economic development. J Monetary Econ 22:3-42

Markusen J, Venables A (1999) Foreign direct investment as a catalyst for industrial development. Eur Econ Rev 43:335-56

Meade JE (1955) The theory of Customs Unions. North-Holland, Amsterdam

Mundell R (1957) International trade and factor mobility. Am Econ Rev 47(3):321-335

Oates W (1972) Fiscal Federalism. Harcourt Brace Janovich, New York

Pöyhönen P (1963) A tentative model for the volume of trade between countries. Weltwirtschaftliches Archiv 90(1):93-99

Robert E, Kwinder S (1997) Economic growth, international technological spillovers and public policy: theory and empirical evidence from Asia. Indian Manag Stud J 4(2)

Rodriguez F, Rodrik D (2000) Trade policy and economic growth: a skeptic's guide to the cross-national evidence. Macroeconomics Annual 2000, MIT Press, Boston

Romer P (1990) Endogenous technological change. J Political Econ 98(5):S71-S102

Sachs J, Warner (1995) Economic reform and the process of global integration. Brookings papers on economic activity

Shiff M, Winters A (2003) Intégration Régionale et Développement, The World Bank, Washington, Economica, Paris

Tinbergen J (1962) An analysis of world trade flows. In: Tinbergen J (ed) Shaping the world economy. Twentieth Century Fund, New York

Vanhoudt P (1999) Did the European unification induce economic growth? In search of scale effects and persistent changes. Rev World Econ 135(2):193-220

Viner J (1950) The Customs Union Issue. Carnegie Endowment for International Peace, New York

WDI (2009) Base de données des indicateurs de développement de la Banque mondiale 